\title{
Nitrogen deposition and increased carbon accumulation in ombrotrophic peatlands in eastern Canada
}

\author{
Jukka Turunen, ${ }^{1}$ Nigel T. Roulet, ${ }^{1,2}$ and Tim R. Moore ${ }^{1}$ \\ Department of Geography, McGill University, Montreal, Quebec, Canada
}

Pierre J. H. Richard ${ }^{1}$

Département de Géographie, Université de Montréal, Montreal, Quebec, Canada

Received 23 September 2003; revised 25 March 2004; accepted 19 April 2004; published 10 July 2004.

[1] Recent and long-term accumulation rates of carbon (C), using ${ }^{210} \mathrm{~Pb}$ - and ${ }^{14} \mathrm{C}$-dating, were examined in 23 ombrotrophic peatlands in eastern Canada, where average 1990-1996 atmospheric wet nitrogen $(\mathrm{N})$ deposition ranged from 0.3 to $0.8 \mathrm{~g} \mathrm{~N} \mathrm{~m}^{-2} \mathrm{yr}^{-1}$. The average recent rate of $\mathrm{C}$ accumulation (RERCA) over the past 150 years was $73 \pm$ 17 (SD) $\mathrm{g} \mathrm{C} \mathrm{m}^{-2} \mathrm{yr}^{-1}$, ranging from 40 to $117 \mathrm{~g} \mathrm{C} \mathrm{m}^{-2} \mathrm{yr}^{-1}$. The difference in RERCA between hummocks $\left(78 \mathrm{~g} \mathrm{C} \mathrm{m}^{-2} \mathrm{yr}^{-1}\right)$ and hollows $\left(65 \mathrm{~g} \mathrm{C} \mathrm{m}^{-2} \mathrm{yr}^{-1}\right)$ was significant. Increased RERCA over the past 50 years was found in hummocks and hollows in regions of higher $\mathrm{N}$ deposition and related to both elevated $\mathrm{N}$ deposition and growing degree-days above $+5^{\circ} \mathrm{C}$. There was a statistically significant positive relationship between $\mathrm{N}$ deposition alone and present-day $\mathrm{C}$ accumulation in both hummocks and hollows $\left(\mathrm{R}^{2}=0.28\right.$ and 0.38 , respectively). Recent $\mathrm{N}$ accumulation was significantly larger in high $\mathrm{N}$ deposition regions. The total average aboveground vegetation biomass of hollows and hummocks did not differ significantly with $\mathrm{N}$ deposition. However, a significantly larger vascular plant leaf biomass was found in both hollows and hummocks of the high $\mathrm{N}$ deposition class than in the low $\mathrm{N}$ deposition class $\left(>0.6\right.$ and $<0.4 \mathrm{~g} \mathrm{~m}^{-2} \mathrm{yr}^{-1}$, respectively). The average long-term apparent rate of $\mathrm{C}$ accumulation (LORCA) at 15 sites was $19 \pm 8$ (SD) $\mathrm{g} \mathrm{C} \mathrm{m}^{-2} \mathrm{yr}^{-1}$, with no significant difference due to age of peat inception, latitude, or continentality. INDEX TERMS: 4806 Oceanography: Biological and Chemical: Carbon cycling; 0315 Atmospheric Composition and Structure: Biosphere/atmosphere interactions; 1615 Global Change: Biogeochemical processes (4805); 1040 Geochemistry: Isotopic composition/chemistry; KEYWORDS: carbon accumulation, nitrogen, ombrotrophic peatlands, raised bogs, ${ }^{210} \mathrm{~Pb}$ dating, Canada

Citation: Turunen, J., N. T. Roulet, T. R. Moore, and P. J. H. Richard (2004), Nitrogen deposition and increased carbon accumulation in ombrotrophic peatlands in eastern Canada, Global Biogeochem. Cycles, 18, GB3002, doi:10.1029/2003GB002154.

\section{Introduction}

[2] Global concern over rising atmospheric $\mathrm{CO}_{2}$ concentration has led to attempts to ascertain the role of terrestrial ecosystems in the global carbon (C) cycle. Forests and peatlands in the Northern Hemisphere have been identified as potentially large sinks for organic C [Tans et al., 1990; Gorham, 1991; Kauppi et al., 1992; Houghton, 1993]. On a global scale, the occurrence of peatlands is strongly related to topography and climate, with the greatest abundance found on flat land areas of cool and moist climates, such as western Siberia, Russia, and the Hudson Bay Lowlands of Canada [Sjörs, 1959; Botch et al., 1995].

\footnotetext{
${ }^{1}$ Also at Centre for Climate and Global Change Research, McGill University, Montreal, Quebec, Canada.

${ }^{2}$ Also at McGill School of Environment, McGill University, Montreal, Quebec, Canada.
}

Copyright 2004 by the American Geophysical Union. 0886-6236/04/2003GB002154\$12.00
Organic peat deposits are characterized by $\mathrm{C}$ contents of approximately $50 \%$ of dry matter [Gorham, 1991; Turunen et al., 2001, 2002]. Therefore the abundance of peat signals a significant net transfer of $\mathrm{C}$ from the atmosphere to soils.

[3] Gorham [1991] has estimated the total area of boreal and subarctic peatlands to be 346 million ha and that 200 to $455 \mathrm{Pg} \mathrm{C}$ has accumulated during the Holocene [Gorham, $1990,1991]$ with an update of 270 to $370 \mathrm{Pg} \mathrm{C}$ [Turunen et al., 2002]. Despite the uncertainties in the storage estimates, peatlands are a substantial reservoir of $\mathrm{C}$ in the boreal and subarctic regions, constituting at least one fifth of the total soil C pool in the world [Post et al., 1982], and being approximately half the amount of $\mathrm{CO}_{2}-\mathrm{C}$ in the atmosphere [Houghton et al., 1990].

[4] Peatlands generally accumulate $\mathrm{C}$ because the rate of biomass production is greater than the rate of decomposition. The average long-term apparent rate of carbon accumulation (LORCA) for boreal and subarctic regions throughout the Holocene is estimated at 15 to $30 \mathrm{~g} \mathrm{C} \mathrm{m}^{-2} \mathrm{yr}^{-1}$ 


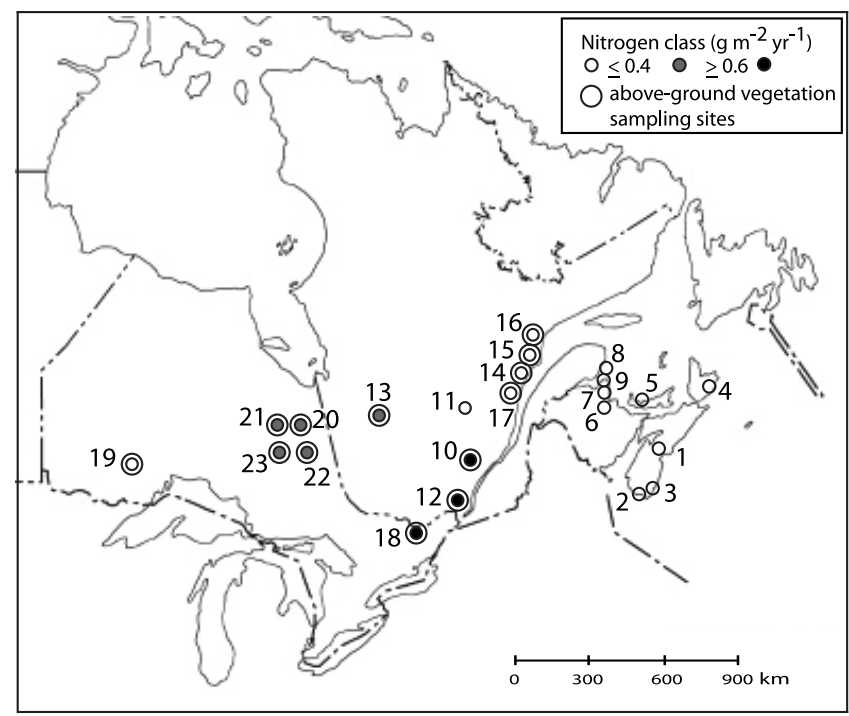

Figure 1. Location and $\mathrm{N}$ deposition class of the 23 ombrotrophic peatlands sampled in eastern Canada. The aboveground vegetation biomass sampling sites are also shown.

[Gorham, 1990, 1991; Vitt et al., 2000; Turunen et al., 2001, 2002]. Eddy covariance and hydrological measurements at the Mer Bleue peatland, near Ottawa, Canada, indicate an annual sink of approximately $60 \mathrm{~g} \mathrm{C} \mathrm{m}^{-2}$ for the last 3 years [Lafleur et al., 2001]: a rate 3 times greater than the long-term accumulation inferred from peat cores in the same peatland (P. J. H. Richard, unpublished data, 2004).

[5] There are a number of reasons why current Mer Bleue $\mathrm{C}$ accumulation rates may be higher: Climate variability, nitrogen deposition, and response to elevated $\mathrm{CO}_{2}$. $\mathrm{CO}_{2}$ response should be universal and not isolated to eastern Canada. Recent studies have indicated that while plant $\mathrm{C}$ allocation changes in response to elevated $\mathrm{CO}_{2}$, there is no significant increase in overall peatland net primary production [Berendse et al., 2001]. Long-term climate variability likely alters $\mathrm{C}$ accumulation on a decadal scale but is also spatially extensive, for example, climate variability associated with the North Atlantic/Arctic Oscillation affects most of northeastern North America. However, nitrogen $(\mathrm{N})$ deposition varies across eastern North America and may affect $\mathrm{C}$ accumulation through effects on plant productivity and rates of organic matter decomposition. Mer Bleue is located in a region of some of the highest $\mathrm{N}$ deposition in eastern North America ( $\left.\sim 0.8 \mathrm{~g} \mathrm{~N} \mathrm{~m}^{-2} \mathrm{yr}^{-1}\right)$, while the Maritimes receive moderate levels of $\mathrm{N}$ deposition and the lowest rates are observed in northwestern Ontario $\left(\sim 0.3 \mathrm{~g} \mathrm{~N} \mathrm{~m}^{-2} \mathrm{yr}^{-1}\right)$.

[6] The specific objective of the research was to investigate the recent (RERCA) and long-term (LORCA) rates of carbon accumulation of 23 ombrotrophic bogs in eastern Canada and to test for relationships of these rates with $\mathrm{N}$ deposition and other environmental variables. Also, the recent rates of nitrogen accumulation (RERNA) were investigated.

\section{Materials and Methods}

\subsection{Study Area and Sampling}

[7] Twenty-three ombrotrophic bogs were selected (Figure 1, Table 1) based on the work of Gorham et al. [1985], Damman and Dowhan [1981], Glaser and Janssens [1986], and Damman [1988]. All peatlands were characterized by an open canopy of Picea mariana (approximately treeless), with Chamaedaphne calyculata, Ledum groenlandicum, Kalmia angustifolia, Kalmia polifolia, Vaccinium uliginosum, Vaccinium myrtilloides, Vaccinium oxycoccos, Andromeda polifolia, and scattered Eriophorum spissum. In coastal regions, the shrub cover was less dominant compared to more continental areas. However, the same species were found in all sampled bogs. A few Pinus banksiana and Larix laricina were found as a mixture with Picea mariana in several peatlands of Ontario and Québec. Hummocks were dominated by Sphagnum fuscum, with scattered S. magellanicum, S. capillifolium, Polytrichum spp., Cladina spp., Empetrum nigrum, and Sarracenia purpurea, and hollows by $S$. rubellum and $S$. angustifolium. In coastal regions, $S$. flavicomans was commonly found in the sampled hummocks as a mixture with S. fuscum. Scattered Juniperus communis was also found in the hummocks of peatlands near the Atlantic Ocean.

[8] The RERCA and RERNA were measured at all 23 bogs by collecting three short cores $(50 \mathrm{~cm})$ using a box sampler $(85 \times 85 \times 1000 \mathrm{~mm})$, two from hummock sites and one from a hollow site. Each short core was double-wrapped in polythene bags, and stored at $-4^{\circ} \mathrm{C}$. Additional peat samples were collected down to $80 \mathrm{~cm}$ for each core in case they were needed for further analysis. The LORCA was measured at 15 bogs (Table 2). Complete peat profiles with contiguous $10-\mathrm{cm}$ intervals were collected from hummock sites for dry bulk density measurements with the box sampler and a Russian pattern side-cutting peat sampler $(50 \times 500 \mathrm{~mm})$. The degree of decomposition was estimated in the field with von Post's [1922] 10-grade scale $\left(\mathrm{H}_{1-10}\right)$. Basal peat samples from the coring sites were taken for ${ }^{14} \mathrm{C}$ dating. The aboveground vegetation was collected from $0.25 \mathrm{~m}^{2}$ plots at two or more hummock sites and one hollow site at 13 bogs (Figure 1).

\subsection{Laboratory Analyses}

[9] The peat samples were dried to a constant mass at $70^{\circ} \mathrm{C}$ and weighed and the dry bulk density calculated by dividing the dry mass by the fresh volume. The $\mathrm{C}$ and $\mathrm{N}$ concentrations of peat were analyzed using a Elementar vario EL analyzer at University of Bayreuth, Germany [Tabatabai and Bremer, 1990]. The cumulative dry mass of peat on an areal basis $\left(\mathrm{g} \mathrm{m}^{-2}\right)$ was calculated as layer thickness weighted averages from the dry bulk density profile and converted into $\mathrm{C}$ and $\mathrm{N}$, based on $\mathrm{C}$ and $\mathrm{N}$ concentration analyses for surface cores (max top $80 \mathrm{~cm}$ ) and $51.7 \%$ of $\mathrm{C}$ for long cores [Gorham, 1991]. The accumulated mass of $\mathrm{C}$ and $\mathrm{N}$ above the oldest ${ }^{210} \mathrm{~Pb}$-datable horizon was divided by the age of this horizon to give the RERCA ( $\mathrm{g} \mathrm{C} \mathrm{m}^{-2} \mathrm{yr}^{-1}$ ) and RERNA $\left(\mathrm{g} \mathrm{N} \mathrm{m}^{-2} \mathrm{yr}^{-1}\right)$. The LORCA was determined similarly, but using the $\mathrm{C}$ mass above the peat-mineral contact, and the age of the basal peat sample. The Mer Bleue Bog was the exception, in that the 
Table 1. Location and Characteristics of Ombrotrophic Peatlands Sampled in Canada (See Also Figure 1) and Characteristics of the Sites in the Three N Deposition Classes ${ }^{\mathrm{a}}$

\begin{tabular}{|c|c|c|c|c|c|c|c|c|c|c|c|}
\hline \multirow[b]{2}{*}{$\mathrm{N}$ Class } & \multirow[b]{2}{*}{ Peatland } & \multirow[b]{2}{*}{$\begin{array}{l}\text { North } \\
\text { Latitude } \\
\end{array}$} & \multirow[b]{2}{*}{$\begin{array}{c}\text { West } \\
\text { Longitude } \\
\end{array}$} & \multicolumn{3}{|c|}{ Mean Temperature, ${ }^{\circ} \mathrm{C}$} & \multirow{2}{*}{$\begin{array}{c}\text { Effective } \\
\text { Temperature } \\
\text { Sum, dd }\end{array}$} & \multicolumn{3}{|c|}{ Annual Precipitation } & \multirow[b]{2}{*}{$\begin{array}{l}\text { N Deposition, } \\
\mathrm{g} \mathrm{m}^{-2} \mathrm{yr}^{-1}\end{array}$} \\
\hline & & & & January & July & Annual & & $\begin{array}{c}\text { Rain, } \\
\mathrm{mm}\end{array}$ & $\begin{array}{c}\text { Snow, } \\
\mathrm{cm}\end{array}$ & $\begin{array}{c}\text { Total, } \\
\mathrm{mm}\end{array}$ & \\
\hline \multirow[t]{16}{*}{1} & 1 Petite Bog, NS & $45^{\circ} 09^{\prime}$ & $63^{\circ} 56^{\prime}$ & -5.7 & 17.1 & 6.5 & 1602 & 944 & 230 & 1175 & $0.34(0.08)$ \\
\hline & 2 Western Head, NS & $43^{\circ} 41^{\prime}$ & $65^{\circ} 08^{\prime}$ & -1.6 & 11.3 & 5.9 & 1000 & 1068 & 149 & 1217 & $0.33(0.04)$ \\
\hline & 3 Cape Sable, NS & $43^{\circ} 28^{\prime}$ & $65^{\circ} 36^{\prime}$ & -1.6 & 11.3 & 5.9 & 1000 & 1068 & 149 & 1217 & $0.33(0.04)$ \\
\hline & 4 Fourchu, NS & $45^{\circ} 42^{\prime}$ & $60^{\circ} 14^{\prime}$ & -5.4 & 17.6 & 5.5 & 1444 & 1156 & 330 & 1480 & $0.29(0.03)$ \\
\hline & 5 Foxley Moor, P.E.I. & $46^{\circ} 43^{\prime}$ & $64^{\circ} 02^{\prime}$ & -8.6 & 18.6 & 5.0 & 1545 & 812 & 278 & 1090 & $0.32(0.08)$ \\
\hline & 6 Point Sapin, NB & $46^{\circ} 59^{\prime}$ & $64^{\circ} 51^{\prime}$ & -10.4 & 19.1 & 4.6 & 1591 & 768 & 324 & 1087 & $0.32(0.08)$ \\
\hline & 7 Point Escuminac, NB & $47^{\circ} 04^{\prime}$ & $64^{\circ} 49^{\prime}$ & -10.4 & 19.1 & 4.6 & 1591 & 768 & 324 & 1087 & $0.27(0.06)$ \\
\hline & 8 Miscou Island, NB & $47^{\circ} 56^{\prime}$ & $64^{\circ} 30^{\prime}$ & -10.4 & 19.1 & 4.6 & 1611 & 710 & 308 & 1018 & $0.28(0.07)$ \\
\hline & 9 Savoy Bog, NB & $47^{\circ} 47^{\prime}$ & $64^{\circ} 36^{\prime}$ & -10.4 & 19.1 & 4.6 & 1611 & 710 & 308 & 1018 & $0.28(0.07)$ \\
\hline & 11 Yellow Lake, Qc & $48^{\circ} 54^{\prime}$ & $71^{\circ} 54^{\prime}$ & -17.0 & 17.3 & 1.5 & 1363 & 637 & 197 & 835 & $0.32(0.06)$ \\
\hline & 14 Ilets-Jeremie Bog, Qc & $48^{\circ} 54^{\prime}$ & $68^{\circ} 49^{\prime}$ & -14.0 & 15.6 & 1.5 & 1026 & 662 & 362 & 996 & $0.35(0.06)$ \\
\hline & 15 Mai Bog, Qc & $49^{\circ} 57^{\prime}$ & $67^{\circ} 02^{\prime}$ & -14.6 & 15.2 & 1.0 & 947 & 729 & 415 & 1128 & $0.33(0.05)$ \\
\hline & 16 Port Cartier Bog, Qc & $50^{\circ} 02^{\prime}$ & $66^{\circ} 56^{\prime}$ & -14.6 & 15.2 & 1.0 & 947 & 729 & 415 & 1128 & $0.29(0.05)$ \\
\hline & 17 Escoumins Bog, Qc & $48^{\circ} 24^{\prime}$ & $69^{\circ} 21^{\prime}$ & -12.5 & 16.9 & 3.0 & 1284 & 691 & 310 & 998 & $0.36(0.05)$ \\
\hline & 19 Baker Bog, Ont & $49^{\circ} 08^{\prime}$ & $90^{\circ} 45^{\prime}$ & -17.9 & 17.7 & 1.5 & 1338 & 581 & 238 & 763 & $0.35(0.06)$ \\
\hline & Mean & & & $-10.2(4.9)$ & $16.6(2.5)$ & $3.8(1.9)$ & $1320(269)$ & $808(171)$ & $289(83)$ & $1090(160)$ & $0.03)$ \\
\hline \multirow[t]{6}{*}{2} & 13 Despinassy Bog, Qc & $48^{\circ} 44^{\prime}$ & $77^{\circ} 44^{\prime}$ & -14.3 & 16.1 & 1.0 & 1141 & 670 & 244 & 913 & $0.47(0.10)$ \\
\hline & 20 Norembego, Ont & $48^{\circ} 59^{\prime}$ & $80^{\circ} 42^{\prime}$ & -18.2 & 16.7 & 0.6 & 1206 & 604 & 316 & 920 & $0.52(0.12)$ \\
\hline & 21 Nellie Bog, Ont & $48^{\circ} 46^{\prime}$ & $80^{\circ} 50^{\prime}$ & -17.6 & 17.1 & 0.9 & 1252 & 573 & 219 & 793 & $0.52(0.12)$ \\
\hline & 22 Hislop Bog, Ont & $48^{\circ} 28^{\prime}$ & $80^{\circ} 23^{\prime}$ & -17.1 & 17.7 & 1.5 & 1335 & 587 & 289 & 876 & $0.52(0.12)$ \\
\hline & 23 Holtrye Bog, Ont & $48^{\circ} 32^{\prime}$ & $80^{\circ} 48^{\prime}$ & -17.6 & 17.1 & 0.9 & 1252 & 573 & 219 & 793 & $0.52(0.12)$ \\
\hline & Mean & & & $-17.4(1.0)$ & $17.0(0.4)$ & $0.9(0.3)$ & $1245(54)$ & $591(28)$ & $257(43)$ & $848(60)$ & $0.51(0.02)$ \\
\hline \multirow[t]{4}{*}{3} & 10 Lac à la Tortue, Qc & $46^{\circ} 32^{\prime}$ & $72^{\circ} 40^{\prime}$ & -12.7 & 19.6 & 4.6 & 1738 & 783 & 250 & 1042 & $0.76(0.14)$ \\
\hline & 12 Mirabel, Qc & $45^{\circ} 41^{\prime}$ & $74^{\circ} 03^{\prime}$ & -11.7 & 19.7 & 4.8 & 1748 & 796 & 233 & 1030 & $0.81(0.12)$ \\
\hline & 18 Mer Bleue, Ont & $45^{\circ} 25^{\prime}$ & $75^{\circ} 31^{\prime}$ & -10.8 & 20.8 & 5.8 & 1941 & 702 & 222 & 910 & $0.81(0.13)$ \\
\hline & Mean & & & $-11.7(1.0)$ & $20.0(0.7)$ & $5.1(0.6)$ & $1821(109)$ & $753(47)$ & $235(14)$ & $987(70)$ & $0.79(0.02)$ \\
\hline
\end{tabular}

${ }^{\mathrm{a}}$ Class 1: $<0.4$; class 2: $0.4-0.6$; class 3: $>0.6 \mathrm{~g} \mathrm{~N} \mathrm{~m}^{-2} \mathrm{yr}^{-1}$. For effective temperature sum, $\mathrm{a}+5^{\circ} \mathrm{C}$ threshold is used, dd is degree-days. Standard deviation (SD) in parentheses. NS, Nova Scotia; P.E.I., Prince Edward Island; NB, New Brunswick; Qc, Québec; Ont, Ontario.

basal $70 \mathrm{~cm}$ of the limnic peat was excluded from the LORCA analysis, and the pond-fen transition zone (500 $\mathrm{cm}$ ) was used as a basal peat depth.

[10] Ten samples of $1 \mathrm{~cm}$ thickness were taken from each peat core at 5-cm intervals and submitted to Flett Research Ltd., Winnipeg, Canada for ${ }^{210} \mathrm{~Pb}$ dating. Similarly, extra samples from 50 to $80 \mathrm{~cm}$, especially from hummock sites, were also analyzed if the unsupported ${ }^{210} \mathrm{~Pb}$ activity was much greater than the supported ${ }^{210} \mathrm{~Pb}$ activity (i.e., measured activity had not reached the low natural ${ }^{210} \mathrm{~Pb}$ background activity). The theory of ${ }^{210} \mathrm{~Pb}$-dating $\left(\mathrm{t}_{1 / 2}=\right.$
22.3 years) assumes that ${ }^{210} \mathrm{~Pb}$ concentrations in peat decrease exponentially with depth, approaching a low constant value taken to represent the supported ${ }^{210} \mathrm{~Pb}$ fraction formed within soil as opposed to that deposited from the atmosphere [e.g., Turetsky et al., 2000]. A dry $0.5-\mathrm{g}$ subsample from each peat layer was analyzed for ${ }^{210} \mathrm{~Pb}$ activity (as estimated by the alpha emitting ${ }^{210} \mathrm{Po}$ granddaughter), after spiking with a ${ }^{209}$ Po yield tracer. The constant rate of supply (CRS) model of Appleby and Oldfield [1978] was applied to calculate the ages of peat layers. The $\mathrm{C}$ accumulation of the last 50 years was used as

Table 2. Basal Sample Characteristics and the Results of ${ }^{14} \mathrm{C}$ Dating in Ombrotrophic Peatlands of Eastern Canada ${ }^{\mathrm{a}}$

\begin{tabular}{|c|c|c|c|c|c|c|c|}
\hline Site & $\begin{array}{c}\text { Sample } \\
\text { Depth, cm }\end{array}$ & Peat Material & Lab. Number & ${ }^{13} \mathrm{C} /{ }^{12} \mathrm{C}$ & $\begin{array}{l}{ }^{14} \mathrm{C} \text { Date, } \\
\text { Year BP }\end{array}$ & $\begin{array}{c}\text { Calendar Date, } \\
\text { Year BP }\end{array}$ & $\begin{array}{l}\text { LORCA, } \\
\mathrm{g} \mathrm{C} \mathrm{m}^{-2} \mathrm{yr}^{-1}\end{array}$ \\
\hline 1 Petite Bog, NS & $340-345$ & L-C, H5 & Beta-151184 & -26.8 & $3450 \pm 70$ & 3750 & 27.8 \\
\hline 2 Western Head, NS & $585-590$ & C, H6-7 & Beta-151185 & -27.8 & $7970 \pm 120$ & 8920 & 18.5 \\
\hline 4 Fourchu, NS & $145-150$ & N-Er-C, H4-5 & Beta- 151186 & -27.1 & $2380 \pm 50$ & 2410 & 16.1 \\
\hline 5 Foxley Moor, P.E.I. & $105-110$ & Pr-C, H7 & Beta-151187 & -25.5 & $7840 \pm 70$ & 8660 & 5.8 \\
\hline 6 Point Sapin, NB & $340-345$ & Eq-C, H9 & Beta-151188 & -25.7 & $6460 \pm 70$ & 7460 & 13.2 \\
\hline 7 Point Escuminac, NB & $495-500$ & N-S-C, H9 & Beta-151189 & -27.5 & $4170 \pm 60$ & 4800 & 28.6 \\
\hline 8 Miscou Island, NB & $630-635$ & $\mathrm{~N}-\mathrm{S}, \mathrm{H} 4-5$ & Beta- 151190 & -27.1 & $8070 \pm 100$ & 9060 & 22.9 \\
\hline $10 \mathrm{Lac}$ à la Tortue, Qc & $415-420$ & $\mathrm{C}, \mathrm{H} 9$ & Beta-151191 & -28.0 & $8150 \pm 70$ & 9090 & 16.6 \\
\hline 11 Yellow Lake, Qc & $290-295$ & C, H7-8 & Beta-151192 & -28.8 & $5420 \pm 60$ & 6290 & 18.0 \\
\hline 13 Despinassy Bog, Qc & $145-150$ & C-B, H4 & Beta-151193 & -26.9 & $6760 \pm 70$ & 7650 & 5.1 \\
\hline 14 Ilets-Jeremie Bog, Qc & $370-375$ & N-Sch-S-C, H5 & Beta-151194 & -26.9 & $3570 \pm 60$ & 3910 & 34.6 \\
\hline 16 Port Cartier Bog, Qc & $265-270$ & $\mathrm{~N}-\mathrm{S}, \mathrm{H} 8$ & Beta-151195 & -26.8 & $5750 \pm 70$ & 6580 & 17.3 \\
\hline 18 Mer Bleue, Ont & $475-480$ & $\mathrm{~N}-\mathrm{S}-\mathrm{C}, \mathrm{H} 5$ & TO-8163 & - & $7340 \pm 70$ & 8170 & 24.3 \\
\hline 19 Baker Bog, Ont & $215-220$ & Sch-C, H5 & Beta-151196 & -26.3 & $8700 \pm 80$ & 9710 & 10.0 \\
\hline 20 Norembego, Ont & $320-325$ & L-S, H6-7 & Beta-151197 & -26.7 & $5540 \pm 50$ & 6360 & 23.5 \\
\hline
\end{tabular}

${ }^{a}$ LORCA, the long-term apparent rate of carbon accumulation. Peat constituents: B, Bryales; C, Carex; Er, Eriophorum; Eq, Equisetum; L, wood; N, shrub; Pr, Phragmites; S, Sphagnum; Sch, Scheuchzeria; H, degree of decomposition in von Post's [1922] ten-grade scale. Calendar date refers to the calibrated calendar years [Stuiver and Reimer, 1993]. 
the basis mass for $\mathrm{C}$ loss comparison because ${ }^{210} \mathrm{~Pb}$-dating has proven most reliable for peat deposits in the range of 50-200 years [Malmer and Holm, 1984].

[11] Basal peat samples were ${ }^{14} \mathrm{C}$ dated at the Beta Analytical Dating Laboratory, Florida, and University of Toronto, Ontario, Canada. All results were corrected for isotopic fractionation based on the ${ }^{13} \mathrm{C}$-values (Table 2) and radiocarbon ages were converted to calendar years using CALIB 3.0.3 [Stuiver and Reimer, 1993]. All ages used in this article are calendar years (cal. BP).

[12] Aboveground biomass was separated into vascular leaves and stems and Sphagnum capitulum, dried to a constant mass at $70^{\circ} \mathrm{C}$ and weighed [Moore et al., 2002].

[13] The climate data (Table 1) were derived from the Canadian Climate Normals (Meteorological Service of Canada, http://www.msc-smc.ec.gc.ca/climate/climate_normals/ index_e.cfm), using the station nearest each bog. The wet $\mathrm{N}$ deposition $\left(\mathrm{N}-\mathrm{NH}_{4}+\mathrm{N}-\mathrm{NO}_{3}\right)$ was calculated using the 7-year mean (1990-1996) for eastern North America [Vet et al., 1999], using the station nearest each bog. The bogs were allocated to three $\mathrm{N}$ deposition classes: class 1: $<0.4$, class 2 : $0.4-0.6$, class 3: $>0.6 \mathrm{~g} \mathrm{~N} \mathrm{~m}^{-2} \mathrm{yr}^{-1}$ (Table 1).

[14] SPSS for Windows 10.0 statistical software was used to analyze the relationships between variables. The normal distribution and homogeneity of variances were tested using the Kolmogorov-Smirnov and Levene statistical tests. Stepwise, ordinary least squares multiple regression was used to examine which characteristics of the sites (Table 1) were related to the rates of $\mathrm{C}$ accumulation. Pearson's correlation coefficient $r$ was used for correlation analysis. To compare differences in the $\mathrm{C}$ accumulation and in biomass of hollows and hummocks between study sites along the atmospheric $\mathrm{N}$ deposition gradient, analysis of variance (ANOVA) was conducted.

\section{Results}

\section{1. ${ }^{210} \mathrm{~Pb}$ Concentrations}

[15] Mean total residual unsupported (i.e., $\mathrm{Pb}$ deposited by atmospheric processes as opposed to $\mathrm{Pb}$ incorporated into the biomass) ${ }^{210} \mathrm{~Pb}$ activity in the surface cores was $0.35 \pm$ $0.11 \mathrm{~Bq} \mathrm{~cm}{ }^{-2}$ (counting time $500 \mathrm{~min}$ ), with larger mean values in hummocks $\left(0.38 \mathrm{~Bq} \mathrm{~cm}^{-2}\right)$ than hollows $\left(0.30 \mathrm{~Bq} \mathrm{~cm}^{-2}\right)$. The geographic pattern of unsupported ${ }^{210} \mathrm{~Pb}$ burden in peat was similar to that of industrial $\mathrm{N}$ deposition. In $\mathrm{N}$ deposition classes 1, 2, and 3, the average unsupported ${ }^{210} \mathrm{~Pb}$ burden in hollows was $0.25,0.39$, and $0.42 \mathrm{~Bq} \mathrm{~cm}^{-2}$ and in hummocks $0.37,0.38$, and $0.45 \mathrm{~Bq} \mathrm{~cm}{ }^{-2}$, respectively. The ${ }^{210} \mathrm{~Pb}$-dating worked well in all 23 hollows but difficulties arose in some hummocks in the high $\mathrm{N}$-deposition class. These hummocks were characterized by a large shrub biomass and weakly decomposed, loose Sphagnum fuscum. Eight hummocks were subsequently excluded because data inconsistencies in ${ }^{210} \mathrm{~Pb}$-activity throughout the peat columns made it unreliable to construct ${ }^{210} \mathrm{~Pb}$-based chronologies for these cores.

\subsection{Short-Term $C$ Accumulation}

[16] The RERCA over the past 150 years revealed considerable variation among different peatlands, ranging from
40 to $117 \mathrm{~g} \mathrm{C} \mathrm{m}^{-2} \mathrm{yr}^{-1}$ (Table 3). Results from site \# 19 were excluded from the analysis as outliers (Table 3 ). The average dry bulk density and $\mathrm{C}$ concentration among hummocks (42 $\left.\mathrm{g} \mathrm{dm}^{-3}, 46 \%\right)$ and hollows $\left(51 \mathrm{~g} \mathrm{dm}^{-3}\right.$, $46 \%)$ were similar. RERCA was significantly larger in hummocks than in hollows over the past 150 years. Also, the variation in RERCA and cumulative $\mathrm{C}$ mass within hummocks was much less than within hollows (Table 3, Figure 2). Generally, the average net accumulation rate of C decreased with time both in hollows and hummocks because of decay, even though some variation was found among peatlands.

[17] The effect of climate characteristics (Table 1) on RERCA was investigated by stepwise, ordinary least squares multiple regressions (entry level 0.10 ). Since the increase in $\mathrm{N}$ deposition has been mainly in the second half of the twentieth century, the 50-year RERCA was used in this analysis. Multiple regressions revealed significant relationships between recent $\mathrm{C}$ accumulation, climate characteristics, and the $\mathrm{N}$ deposition. The 50-year RERCA rates in hollows and hummocks were best predicted from $\mathrm{N}$ deposition and growing degree-days above $+5^{\circ} \mathrm{C}\left(\mathrm{r}^{2}=\right.$ 0.46 and 0.36, respectively; Figure 3, Table 4). Generally, multicollinearity between climate characteristics was a problem. However, the predictive variables in both regressions were relatively independent $(r=0.44$ and $r=0.31$, respectively). Overall, the relatively weak relationships between climate variables and $\mathrm{C}$ accumulation over the 100 and 150 years were very similar to each other. The 150-year RERCA rates in hollows and hummocks were best predicted from annual total precipitation (negative, $\mathrm{r}^{2}=$ 0.18 and 0.26 , respectively).

[18] Analysis of variance (ANOVA) revealed that RERCA was significantly greater in hummocks than in hollows in $\mathrm{N}$ deposition classes 1 and 2 over the last 50 , 100, and 150 years. Differences in RERCA within high N deposition class 3 , however, were not statistically significant over the last 50,100, and 150 years. Differences in RERCA between classes of different rates of $\mathrm{N}$ deposition were significant. The 50-year RERCA was significantly larger in hollows of the high $\mathrm{N}$ deposition class 3 compared to hollows in lower $\mathrm{N}$ deposition classes 1 and 2 ( $p=0.004$ and $p=0.030$, respectively). The 100 and 150-year RERCA were significantly larger in hollows of high $\mathrm{N}$ deposition class 3 compared to low $\mathrm{N}$ deposition class 1 ( $p=0.005$ and $p=0.007$, respectively). In hummocks, the 50-year RERCA was significantly larger in the high $\mathrm{N}$ deposition class 3 compared to lower $\mathrm{N}$ deposition class $1(p=0.027)$. The 50-year RERCA was significantly larger in the $\mathrm{N}$ deposition class 2 compared to lower $\mathrm{N}$ deposition class $1(p=0.012)$, though differences in 100- and 150-year RERCA were not statistically significant, but the trend was to an increasing RERCA toward the higher $\mathrm{N}$ deposition classes (Table 3).

[19] Assuming that $\mathrm{C}$ input into the acrotelm, the upper oxic zone of the peat profile, has been relatively constant during the last 150 years, the hummock and hollow peat layers from 50 to 100 years have lost approximately $38 \%$ and peat layers from 100 to 150 years have lost approximately $57 \%$ of the original $\mathrm{C}$ mass compared to the recent 
Table 3. Recent Apparent Rate of Carbon Accumulation (RERCA) Based on ${ }^{210} \mathrm{~Pb}$ Dating in Ombrotrophic Peatlands of Eastern Canada

\begin{tabular}{|c|c|c|c|c|c|c|c|}
\hline \multirow[b]{2}{*}{$\mathrm{N}$ Class } & \multirow[b]{2}{*}{ Peatland } & \multicolumn{2}{|c|}{ Hollows } & \multicolumn{2}{|c|}{ RERCA, $\mathrm{g} \mathrm{C} \mathrm{m}^{-2} \mathrm{yr}^{-1}$} & \multicolumn{2}{|c|}{ Hummocks } \\
\hline & & 50 Years & 100 Years & $\sim 150$ Years & 50 Years & 100 Years & $\sim 150$ Years \\
\hline \multirow[t]{16}{*}{1} & 1 Petite Bog, NS & 83.5 & 68.4 & 58.2 & $77.1(15.3)$ & $64.4(3.6)$ & $61.2(5.7)$ \\
\hline & 2 Western Head, NS & 68.9 & 48.6 & 49.7 & $128.7(35.2)$ & $90.6(-)$ & $78.8(-)$ \\
\hline & 3 Cape Sable, NS & 85.0 & 69.1 & 64.8 & $101.3(1.5)$ & $79.3(5.2)$ & - \\
\hline & 4 Fourchu, NS & 67.2 & 52.3 & 43.8 & $109.7(6.0)$ & $77.6(14.6)$ & $61.8(10.4)$ \\
\hline & 5 Foxley Moor, P.E.I. & 97.5 & 92.8 & 81.3 & $115.1(9.9)$ & $113.1(51.6)$ & $92.5(35.1)$ \\
\hline & 6 Point Sapin, NB & 68.6 & 53.3 & 45.3 & $128.2(-)$ & $98.1(-)$ & - \\
\hline & 7 Point Escuminac, NB & 108.3 & 83.3 & 70.8 & $107.6(5.4)$ & $84.2(14.3)$ & $72.8(4.9)$ \\
\hline & 8 Miscou Island, NB & 112.6 & 66.9 & 49.3 & $104.0(4.8)$ & $86.4(2.9)$ & $73.9(0.1)$ \\
\hline & 9 Savoy Bog, NB & 54.0 & 40.3 & 42.4 & $101.6(1.2)$ & $89.9(6.8)$ & $74.0(9.3)$ \\
\hline & 11 Yellow Lake, Qc & 84.1 & 79.8 & 68.9 & $99.5(5.2)$ & $83.7(2.9)$ & $71.0(5.2)$ \\
\hline & 14 Ilets-Jeremie Bog, Qc & 83.9 & 71.2 & 56.7 & $126.4(4.3)$ & $94.1(1.8)$ & $79.3(1.6)$ \\
\hline & 15 Mai Bog, Qc & 32.5 & 69.9 & 68.4 & $102.0(15.7)$ & $83.2(9.2)$ & $68.4(6.4)$ \\
\hline & 16 Port Cartier Bog, Qc & 50.5 & 50.9 & 39.9 & $121.2(3.4)$ & $94.2(11.9)$ & $76.3(9.0)$ \\
\hline & 17 Escoumins Bog, Qc & 130.4 & 92.5 & 76.9 & $128.6(12.8)$ & $104.7(6.1)$ & $84.9(1.1)$ \\
\hline & 19 Baker Bog, Ont & 99.9 & 128.0 & - & $178.1(-)$ & $140.5(-)$ & $121.4(-)$ \\
\hline & Mean & $80.5(26.3)$ & $67.1(16.4)$ & $58.3(13.6)$ & $110.1(17.0)$ & $88.3(16.9)$ & $74.2(12.1)$ \\
\hline \multirow[t]{6}{*}{2} & 13 Despinassy Bog, Qc & 111.9 & 105.7 & 86.0 & - & - & - \\
\hline & 20 Norembego, Ont & 92.6 & 83.8 & 76.5 & $135.1(13.7)$ & $102.8(5.5)$ & $86.7(2.1)$ \\
\hline & 21 Nellie Bog, Ont & 96.0 & 69.5 & 55.2 & $140.0(20.2)$ & $115.4(0.8)$ & $102.7(4.2)$ \\
\hline & 22 Hislop Bog, Ont & 59.4 & 59.6 & 50.9 & $125.3(-)$ & $89.6(-)$ & $78.7(-)$ \\
\hline & 23 Holtrye Bog, Ont & 81.7 & 69.3 & 67.5 & $115.0(11.5)$ & $96.1(7.2)$ & $82.5(6.8)$ \\
\hline & Mean & $88.3(19.4)$ & $77.6(17.9)$ & $67.2(14.6)$ & $131.7(17.7)$ & $102.6(10.5)$ & $88.9(10.4)$ \\
\hline \multirow[t]{4}{*}{3} & 10 Lac à la Tortue, Qc & 117.8 & 89.7 & 75.7 & $138.1(-)$ & $116.4(-)$ & $90.9(-)$ \\
\hline & 12 Mirabel, Qc & 179.6 & 139.2 & 116.1 & $141.2(-)$ & $95.5(-)$ & \\
\hline & 18 Mer Bleue, Ont & 126.2 & 96.3 & 81.4 & $133.5(-)$ & $104.1(-)$ & $89.4(-)$ \\
\hline & Mean & $141.2(33.5)$ & $108.4(26.9)$ & $91.0(21.9)$ & $137.7(3.9)$ & $105.4(10.7)$ & $90.2(1.1)$ \\
\hline
\end{tabular}

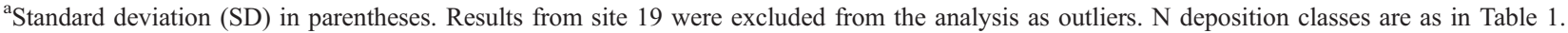

50-year net $\mathrm{C}$ accumulation (Figure 4). The corresponding $\mathrm{C}$ loss values were greater for hummocks (40 and 59\%) than hollows (34 and 52\%) during the last 100 and 150 years, respectively. There was a uniform relative $\mathrm{C}$ mass loss of hollows among different $\mathrm{N}$ deposition classes; that is, the remaining total $\mathrm{C}$ mass increased consistently toward the highest $\mathrm{N}$ deposition class (Figure 4). A similar trend was seen in hummocks over the last 50 years; however, in older hummocks the differences between $\mathrm{N}$ deposition classes were marginal.

\subsection{Long-Term C Accumulation}

[20] The long-term apparent rate of carbon accumulation (LORCA) at 15 sites ranged from 5 to $34 \mathrm{~g} \mathrm{C} \mathrm{m}^{-2} \mathrm{yr}^{-1}$ with an average of $19 \pm 8$ (SD) $\mathrm{g} \mathrm{C} \mathrm{m}^{-2} \mathrm{yr}^{-1}$ (Figure 5, Table 2). LORCA values for sites 5 and 13 were exceptionally small (average $5.5 \mathrm{~g} \mathrm{C} \mathrm{m}^{-2} \mathrm{yr}^{-1}$ ) compared to those of the other study sites (average $20.9 \mathrm{~g} \mathrm{C} \mathrm{m}^{-2} \mathrm{yr}^{-1}$ ). In site 5 (depth $110 \mathrm{~cm}$ ), there were several charcoal layers at short intervals between 72 and $88 \mathrm{~cm}$, suggesting that the shallow peat layers had burned often, and in site 13 (depth $150 \mathrm{~cm}$ ), thick charcoal horizons were found at 50 to $67 \mathrm{~cm}$. No such evidence of peatland fires was found at the other sites. The effect of climate characteristics (Table 1) on LORCA was investigated by stepwise, ordinary least squares multiple regressions. Regression revealed no significant relationships between long-term $\mathrm{C}$ accumulation and present-day climate characteristics. Also, differences in LORCA between present-day $\mathrm{N}$ deposition classes 1,2 , and 3 were not significant $(p=0.96)$. There was a weak relationship between LORCA and RERCA (excluding sites
5,13 and 19, Pearson's correlation coefficient $r=-0.01-$ $0.22, p=0.49-0.98)$ over the last $50-150$ years. Overall, the average RERCA:LORCA ratio for peat deposits of 50, 100 , and 150 years was $8: 1,6: 1$, and 5:1, respectively.

\subsection{Short-Term N Accumulation}

[21] The mean $\mathrm{N}$ concentration of the samples was $0.82 \%$, ranging from 0.35 to $2.25 \%$ with the hollows having a slightly larger average $\mathrm{N}$ concentration $(0.90 \%)$ than the hummocks $(0.76 \%)$. N concentrations were significantly larger in hollows of the higher $\mathrm{N}$ deposition classes 2 and 3 than hollows of low $\mathrm{N}$ deposition class 1 ( $p=0.001$ and $p=0.001$, respectively). In hummocks, $\mathrm{N}$ concentrations were significantly larger in the higher $\mathrm{N}$ deposition classes 2 and 3 than hummocks of low $\mathrm{N}$ deposition class 1 ( $p=$ 0.006 and $p=0.032$, respectively).

[22] The recent rate of nitrogen accumulation (RERNA) decreased with time in both hollows and hummocks. Average RERNA rates over the past 50,100, and 150 years were $1.8,1.7$, and $1.5 \mathrm{~g} \mathrm{~N} \mathrm{~m}^{-2} \mathrm{yr}^{-1}$, respectively. There were significant differences in RERNA among hollows and hummocks in classes of different rates of $\mathrm{N}$ deposition (Figure 6). The 50-year RERNA was significantly larger in hollows of the high $\mathrm{N}$ deposition class 3 than the lower $\mathrm{N}$ deposition class $1(p=0.004)$, but differences between $\mathrm{N}$ deposition classes 2 and 3 were not statistically significant $(p=0.090)$. However, the remaining $\mathrm{N}$ mass of peat layers from 100 to 150 years in the high $\mathrm{N}$ deposition class 3 was not significantly larger than that in the lower $\mathrm{N}$ deposition class $1(p=0.116)$. In hummocks, 50-year RERNA was significantly larger in higher $\mathrm{N}$ deposition classes 2 and 3 

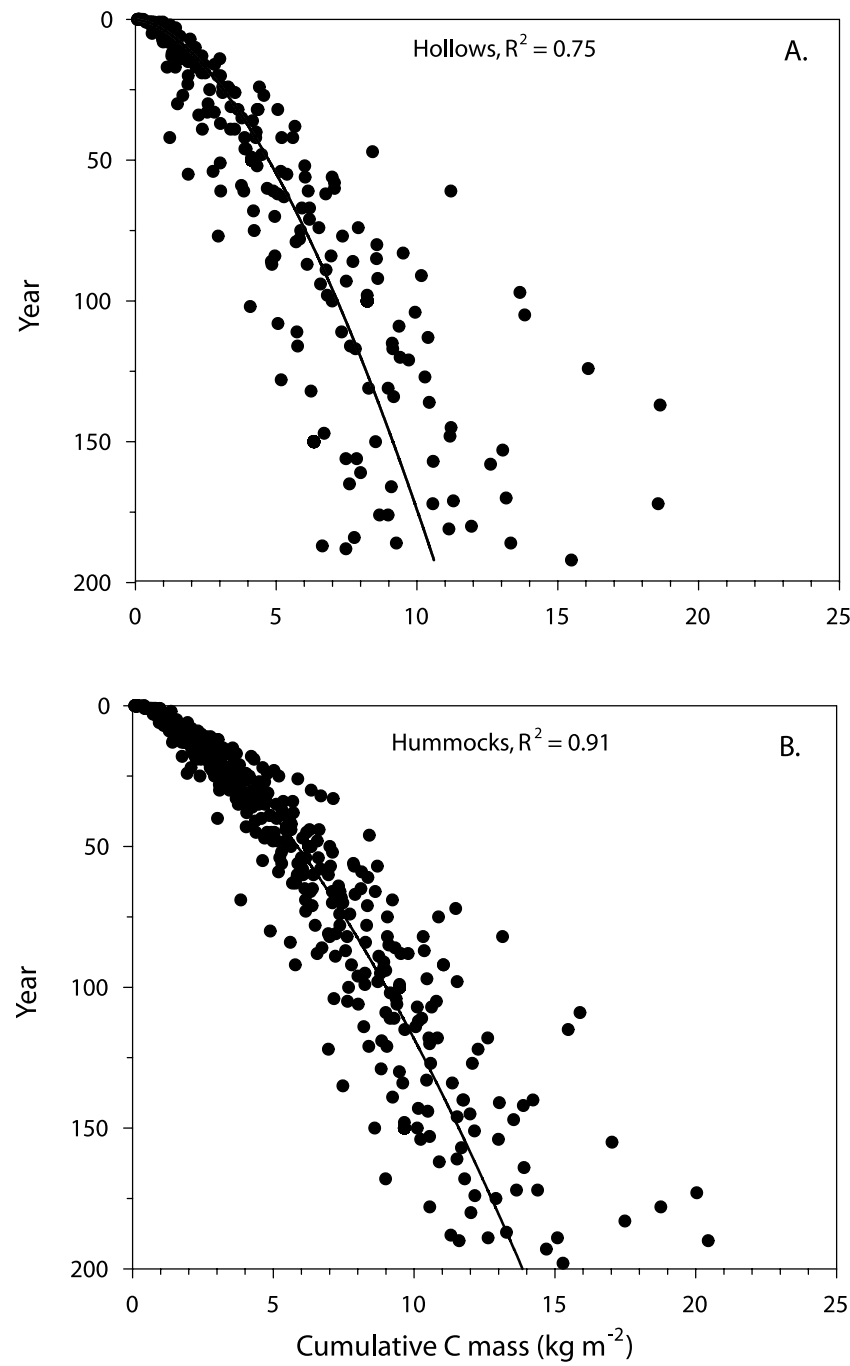

Figure 2. Cumulative $\mathrm{C}$ mass beneath the peat surface ( $\mathrm{kg} \mathrm{C} \mathrm{m}{ }^{-2}$ ) versus year for (a) hollows $(\mathrm{n}=22)$ and (b) hummocks $(\mathrm{n}=36)$. Results from site 19 were excluded from the analysis as extreme outliers.

than low $\mathrm{N}$ deposition class $1(p=0.001$ and $p=0.027$, respectively). As in hollows, the remaining $\mathrm{N}$ mass of hummocks from 100 to 150 years in the high $\mathrm{N}$ deposition class 3 was not significantly larger than that in the lower $\mathrm{N}$ deposition class $1(p=0.593)$.

\subsection{Aboveground Biomass}

[23] Aboveground biomass was significantly greater on hummocks $\left(633 \mathrm{~g} \mathrm{~m}^{-2}\right)$ than in hollows $\left(482 \mathrm{~g} \mathrm{~m}^{-2}\right)$ (Table 5). Differences within different $\mathrm{N}$ deposition classes were evident, with the hummocks and hollows having a similar average Sphagnum capitula biomass within each $\mathrm{N}$ deposition class but a significantly greater vascular plant biomass being present on hummocks than in hollows (Table 5). The ANOVA did not reveal general, significant differences in the total average aboveground vegetation biomass of hollows and hummocks among $\mathrm{N}$ deposition classes. The trend, however, was toward smaller total above- ground biomass in higher $\mathrm{N}$ deposition classes (Table 5). The only statistically significant difference found was with the smaller total average aboveground biomass on the hummocks of the highest $\mathrm{N}$ deposition class 3 compared to the lowest $\mathrm{N}$ deposition class 1 . The general decrease of the total average aboveground biomass seemed to occur in the plant stem and Sphagnum capitula biomass. However, a significantly larger vascular plant leaf biomass was found both in hollows and hummocks of the highest $\mathrm{N}$ deposition class 3 than in classes 1 and 2 (Table 5). We also used stepwise, ordinary least squares multiple regression to examine if the total average aboveground biomass was related to local climate variables (Table 1 ) and/or $\mathrm{N}$ deposition over the last 50 years. The strongest predictor of aboveground biomass in the hummocks was $\mathrm{N}$ deposition $\left(\mathrm{r}^{2}=0.41\right)$ and in the hollows was total precipitation $\left(\mathrm{r}^{2}=0.24\right)$.

\section{Discussion and Conclusions}

\section{1. ${ }^{210} \mathrm{~Pb}$ Dating}

[24] Mean total residual (unsupported) ${ }^{210} \mathrm{~Pb}$ activity in the surface peat cores was $0.35 \mathrm{~Bq} \mathrm{~cm}^{-2}$, well within the range of other soil inventories reported in North America (0.31-0.84 $\mathrm{Bq} \mathrm{cm}^{-2}$ [Urban et al., 1990]). We excluded eight hummocks because of inconsistencies in ${ }^{210} \mathrm{~Pb}$-activity throughout the peat cores, which may have resulted from fires or differential $\mathrm{Pb}$ deposition through the stems of shrubs, allowing partial wet and dry $\mathrm{Pb}$ deposition into deeper peat layers instead of Sphagnum capitula. No other disturbances, such as peat removal, had occurred in the sampling sites. The differences in the ${ }^{210} \mathrm{~Pb}$-activity of the surface moss layers and total ${ }^{210} \mathrm{~Pb}$ burden in hollows and hummocks suggest that there must be differential deposition and/or post-depositional $\mathrm{Pb}$ mobility in some microhabitat types [Damman, 1978; Oldfield et al., 1979; Pakarinen et al., 1983; Urban et al., 1990; Oldfield et al., 1995]. However, several studies have concluded that $\mathrm{Pb}$ remains immobile after deposition on a peat surface [e.g., Livett et al., 1979; Mitchell et al., 1992; Appleby et al., 1997; Vile et al., 1999]. In this study, evidence of possible $\mathrm{Pb}$ mobility was also found in three hollows that showed exceptionally high ${ }^{210} \mathrm{~Pb}$-activity in the surface moss layers, suggesting post-depositional mobility from hummock to hollow or from depth to the surface. Mobility of ${ }^{210} \mathrm{~Pb}$ seems to occur in some microhabitats, depending on different depositional, post-depositional, and geochemical conditions, such as distribution patterns of vegetation and regional differences in precipitation and peatland hydrology.

[25] As a check on the ${ }^{210} \mathrm{~Pb}$ method, at Holtrye bog we were able to compare the ${ }^{210} \mathrm{~Pb}$-dates against a conspicuous charcoal horizon from a 1916 fire as a stratigraphical marker. In 1916, a fire in the Matheson area burned the villages of Kelso, Val Gagne, Porquis Junction, and Iroquois Falls, spreading over 500,000 ha and taking 244 lives (Ontario Ministry of Natural Resources, 2001, available at http://www.mnr.gov.on.ca/MNR/affmb/Fire/Index/About/ Default.htm.). The age difference in hollows and hummocks between the fire and ${ }^{210} \mathrm{~Pb}$-dating method was 4 and 8 years, respectively. Urban et al. [1990] suggested that hummocks are generally more reliable than hollows for preservation of historical records of atmospheric $\mathrm{Pb}$ deposition, and that age 

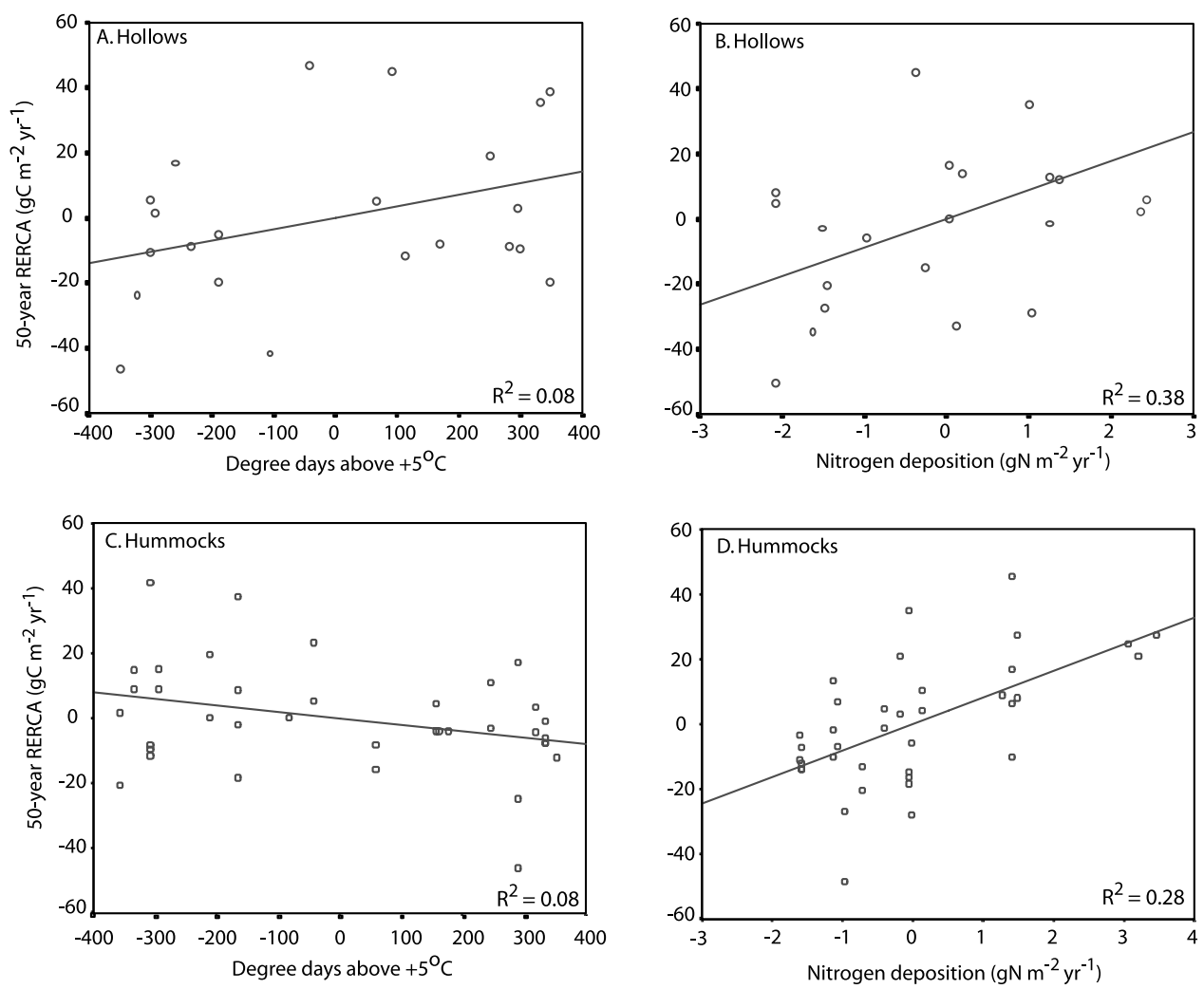

Figure 3. Partial regression plots showing the influence of degree-days above ${ }^{\circ} 5 \mathrm{C}$ and $\mathrm{N}$ deposition, on 50 -year RERCA A-B) in hollows $(n=22)$, and $C-D)$ in hummocks $(n=36)$, while removing the influence of the other independent variables. Results from site \# 19 were excluded from the analysis as extreme outliers.

resolutions no better than \pm 10 years may be attained with the ${ }^{210} \mathrm{~Pb}$-dating technique. Given the possible mobility of $\mathrm{Pb}$, the interpretation of depth-age relationships in peat chronologies via ${ }^{210} \mathrm{~Pb}$-dating has to be made with caution, and data inconsistencies should be taken into account. However, a good agreement between ${ }^{210} \mathrm{~Pb}$-dates in peat and other dating methods suggests that the ${ }^{210} \mathrm{~Pb}$-dating is reliable over the past 200 years where the surface peat is too young for radiocarbon dating [El-Daoushy et al., 1982; Belyea and Warner, 1994; Wieder et al., 1994; Vile et al., 1995; Appleby et al., 1997; Shotyk et al., 1997; Turetsky et al., 2000].

\subsection{Carbon Accumulation}

[26] The $\mathrm{C}$ accumulation rate in eastern Canadian ombrotrophic bogs over the last 150 years ranged from 40 to $117 \mathrm{~g} \mathrm{C} \mathrm{m}^{-2} \mathrm{yr}^{-1}$, with an average of $73 \mathrm{~g} \mathrm{C} \mathrm{m}^{-2} \mathrm{yr}^{-1}$. This is similar to results from Finland (40 to $81 \mathrm{~g} \mathrm{C} \mathrm{m}^{-2}$ $\mathrm{yr}^{-1}$ ) [Tolonen and Turunen, 1996; Pitkänen et al., 1999] and for boreal Sphagnum dominated peat deposits in North

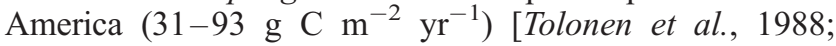
Wieder et al., 1994; Turetsky et al., 2000]. Considerable variation in $\mathrm{C}$ mass accumulation was found both among and within peatlands, and differences in 150-year RERCA between hummocks and hollows were reflected in the average vertical height growth rates (of 4.0 and $2.8 \mathrm{~mm}$ $\mathrm{yr}^{-1}$, respectively). The average vertical height growth rates in hummocks and hollows over the last 50 years were even more distinct ( 8.2 and $4.9 \mathrm{~mm} \mathrm{yr}^{-1}$, respectively). Okland and Ohlson [1998] reported a similar significant difference in vertical height growth between hummocks and hollows over the last 40 years in Scandinavian Sphagnum surface

Table 4. Regressions of the Recent Apparent Rate of Carbon Accumulation (RERCA) in Hollows and Hummocks Over the Last 50 Years $^{\mathrm{a}}$

\begin{tabular}{|c|c|c|c|c|c|}
\hline $\begin{array}{c}\text { Equation } \\
\end{array}$ & d.f. & $\mathrm{F}$ & $\mathrm{P}$ & $r^{2}$ & s.e.est \\
\hline $\begin{array}{l}\text { Fifty-year RERCA rates in hollows, } \mathrm{g} \mathrm{C} \mathrm{m}^{-2} \mathrm{yr}^{-1} \\
\text { RERCA }=4.20+8.91(\mathrm{~N} \text { deposition) }+0.035(\mathrm{dd}) \\
50 \text {-year RERCA rates in hummocks, } \mathrm{g} \mathrm{C} \mathrm{m}^{-2} \mathrm{yr}^{-1}\end{array}$ & 1,20 & 8.2 & 0.003 & 0.46 & 24.9 \\
\hline RERCA $=111.21+8.18(\mathrm{~N}$ deposition $)-0.020(\mathrm{dd})$ & 2,34 & 9.4 & 0.001 & 0.36 & 16.0 \\
\hline
\end{tabular}

${ }^{\mathrm{a}}$ Notation: $\mathrm{dd}$, growing degree-days above $+5^{\circ} \mathrm{C} ; \mathrm{N}$ deposition $\left(\mathrm{g} \mathrm{m}^{-2} \mathrm{yr}^{-1}\right)$, annual mean temperature $\left({ }^{\circ} \mathrm{C}\right)$, s.e.est, standard error of the estimate. 

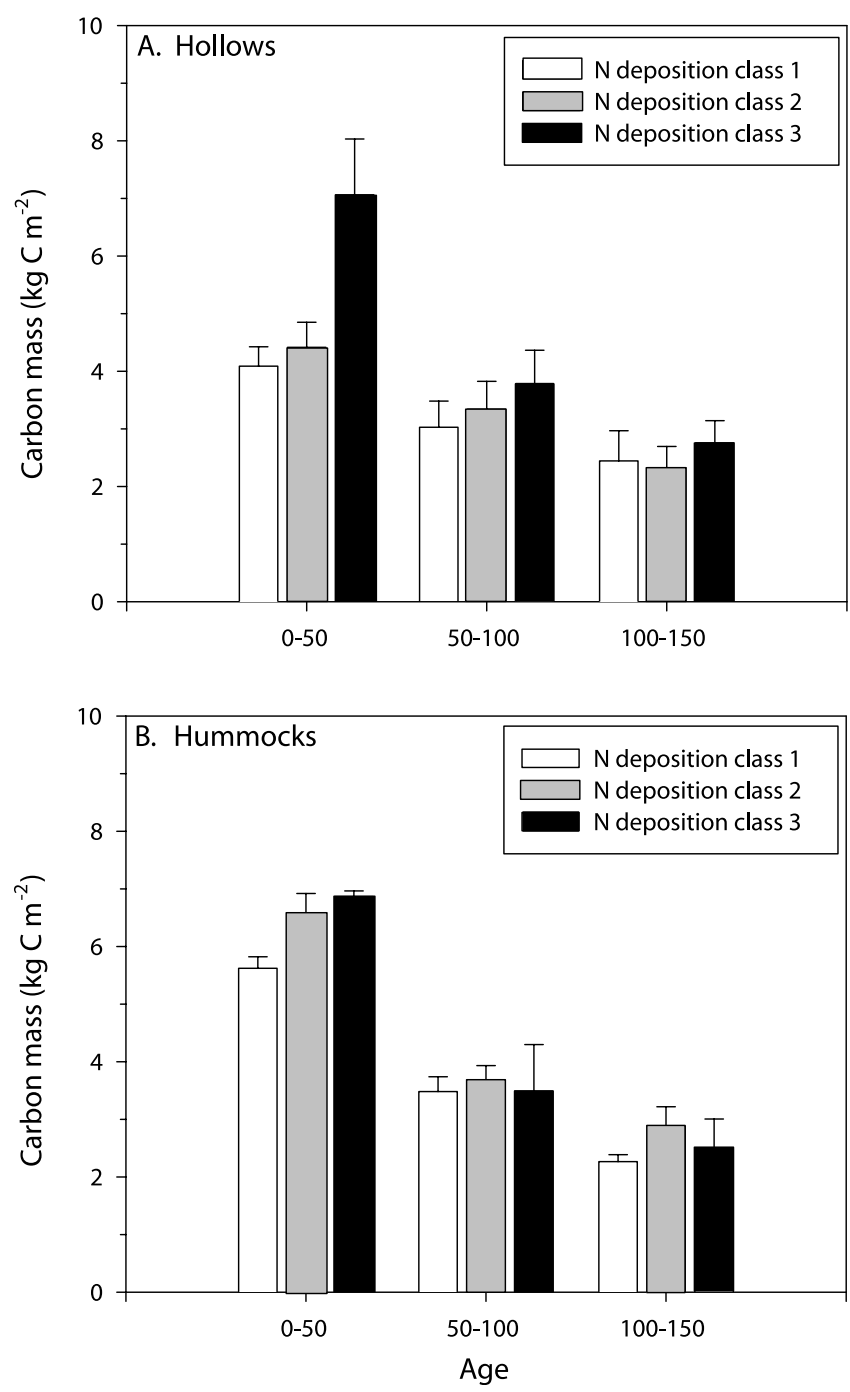

Figure 4. Total $\mathrm{C}$ mass in (a) hollows and (b) hummocks between 0 and 50 years, 50 and 100 years, and 100 and 150 years in three $\mathrm{N}$ deposition classes: class $1:<0.4$, class 2: $0.4-0.6$, class $3:>0.6 \mathrm{~g} \mathrm{~N} \mathrm{~m}^{-2} \mathrm{yr}^{-1}$. Vertical bars are standard errors.

peat. One reason for the RERCA/height growth differences is likely the faster decomposition rate in hollows than hummocks, resulting in larger dry bulk density values. The decomposition rates seem to be largest close to the water table [Belyea, 1996], and has been attributed to optimum conditions of aeration, water, and nutrient availability. Generally, the mean differences in Sphagnum capitulum biomass between hollows and hummocks were marginal (Table 5). However, comparisons are complicated because of a general substantial between-year variation in Sphagnum productivity within the same site [e.g., Lindholm and Vasander, 1990]. A significantly larger vascular plant biomass was found in hummocks than in hollows, which may cause variation in the autogenic factors of these microsites such as temperature and evapotranspiration and thus affect the recent $\mathrm{C}$ accumulation. There are indications that the fine-scale differences in the hydrology of each peatland

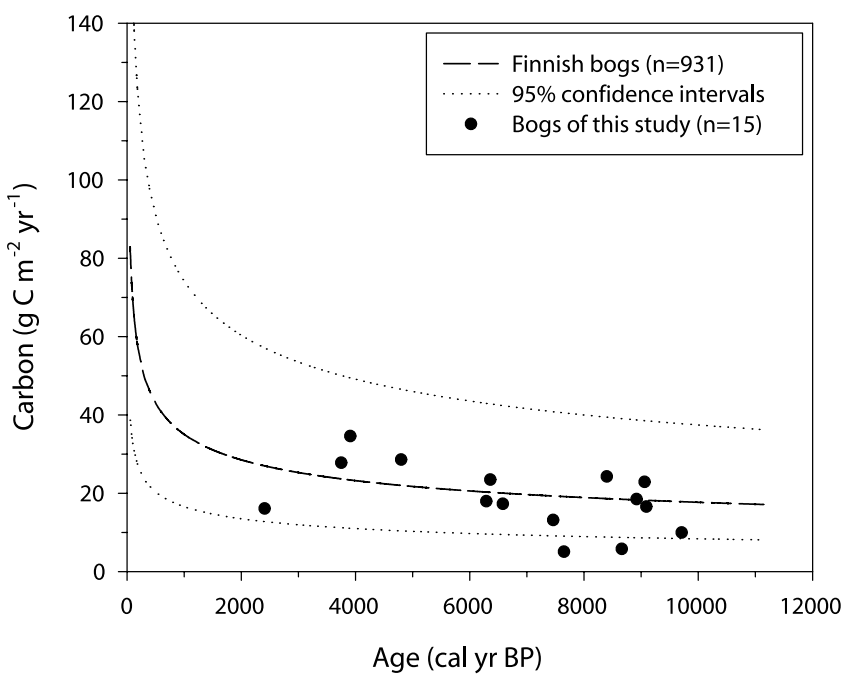

Figure 5. Average long-term apparent rate of carbon accumulation (LORCA) in ombrotrophic peatlands of eastern Canada compared to Finnish bogs [Tolonen and Turunen, 1996; Turunen et al., 2002]. The upper and lower limits of the range of LORCA in Finnish peatlands are also shown.

may play an important role in the observed variations of the aboveground biomass and the present-day C uptake [e.g., Ohlson and Dahlberg, 1991].

[27] The results of our study show that the age of the peat column is an important predictor of $\mathrm{C}$ accumulation rate (Figures 2 and 5, Table 3). The extensive data of Tolonen and Turunen [1996] also showed that the rate of $\mathrm{C}$ accumulation is considerably greater in younger peat deposits and the average net accumulation rate of $\mathrm{C}$ decreases with time because slow decay takes place in the anoxic, deeper peat layers [Clymo, 1984; Gorham, 1991; Tolonen and

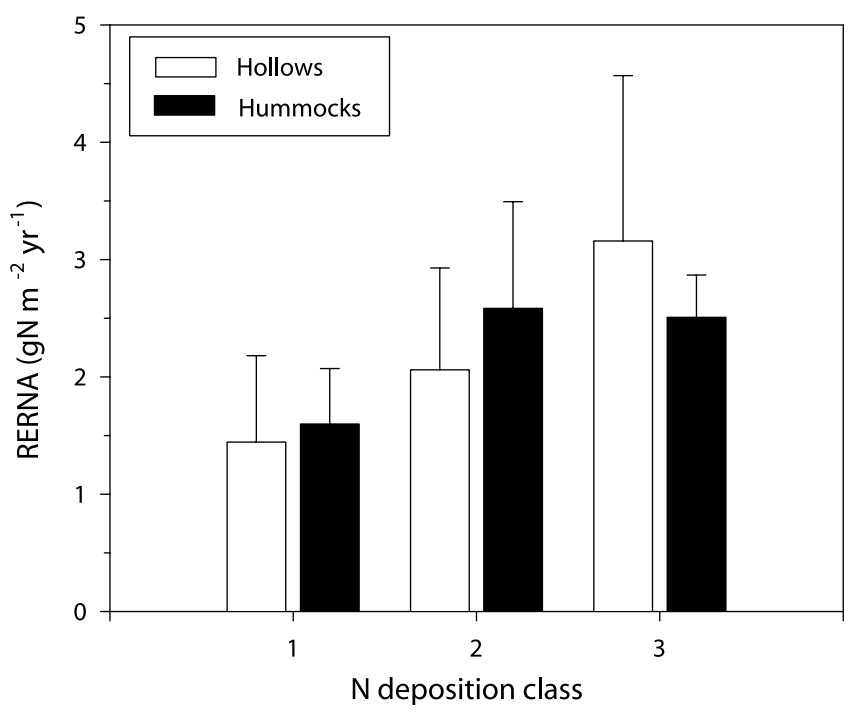

Figure 6. Recent rate of nitrogen accumulation (RERNA) over the last 50 years in hollows and hummocks in ombrotrophic peatlands of eastern Canada. 
Table 5. Average Aboveground Vegetation Biomass of Hollows and Hummocks in Ombrotrophic Peatlands in Eastern Canada ${ }^{a}$

\begin{tabular}{|c|c|c|c|c|c|}
\hline Microsite & $\mathrm{n}$ & $\begin{array}{c}\text { Vascular Leaves, } \\
\mathrm{g} \mathrm{m}^{-2}\end{array}$ & $\begin{array}{c}\text { Vascular Stems, } \\
\mathrm{g} \mathrm{m}^{-2}\end{array}$ & $\begin{array}{c}\text { Sphagnum Capitulum, } \\
\mathrm{g} \mathrm{m}^{-2}\end{array}$ & $\begin{array}{c}\text { Total Biomass, } \\
\mathrm{g} \mathrm{m}^{-2} \\
\end{array}$ \\
\hline $\begin{array}{l}\text { Hollows } \\
\text { Hummocks }\end{array}$ & $\begin{array}{c}5 \\
10\end{array}$ & $\begin{array}{l}95(48)^{\mathrm{b}} \\
150(30)\end{array}$ & $\begin{array}{r}\text { N Deposition Class } 1 \\
272(241) \\
385(184)\end{array}$ & $\begin{array}{l}226(94) \\
190(42)\end{array}$ & $\begin{array}{l}593(331) \\
725(190)\end{array}$ \\
\hline $\begin{array}{l}\text { Hollows } \\
\text { Hummocks }\end{array}$ & $\begin{array}{c}5 \\
10\end{array}$ & $\begin{array}{l}73(24)^{\mathrm{b}} \\
144(32)\end{array}$ & $\begin{array}{r}\text { N Deposition Class } 2 \\
196(95)^{\mathrm{b}} \\
279(73)\end{array}$ & $\begin{array}{l}162(36) \\
180(31)\end{array}$ & $\begin{array}{l}430(117)^{\mathrm{b}} \\
603(78)\end{array}$ \\
\hline $\begin{array}{l}\text { Hollows } \\
\text { Hummocks }\end{array}$ & $\begin{array}{l}4 \\
8\end{array}$ & $\begin{array}{l}162(19)^{\mathrm{c} 1-2} \\
180(23)^{\mathrm{c} 2}\end{array}$ & $\begin{array}{r}\text { N Deposition Class } 3 \\
114(62)^{\mathrm{b}} \\
233(96)^{\mathrm{cl}}\end{array}$ & $\begin{array}{l}131(62) \\
142(43)^{\mathrm{c} 1}\end{array}$ & $\begin{array}{l}407(111)^{\mathrm{b}} \\
555(63)^{\mathrm{c} 1}\end{array}$ \\
\hline $\begin{array}{l}\text { Mean hollows } \\
\text { Mean hummocks } \\
\text { Total mean }\end{array}$ & $\begin{array}{l}14 \\
28 \\
42 \\
\end{array}$ & $\begin{array}{l}106(49)^{\mathrm{b}} \\
156(32) \\
139(45) \\
\end{array}$ & $\begin{array}{l}\text { Mean } \\
\quad 200(161)^{\mathrm{b}} \\
304(140) \\
269(154) \\
\end{array}$ & $\begin{array}{l}176(75) \\
172(43) \\
174(55) \\
\end{array}$ & $\begin{array}{l}482(220)^{\mathrm{b}} \\
633(143) \\
582(184) \\
\end{array}$ \\
\hline
\end{tabular}

Turunen, 1996; Clymo et al., 1998]. However, the 50-, 100-, and 150-year RERCA of both hollows and hummocks was not related to the age of the basal peat in this study (Tables 2 and 3); that is, the recent $\mathrm{C}$ accumulation was not less in older bogs than in younger ones. Our sample size, however, is relatively small, with only three bogs having a basal age younger than 4000 years, so the effect of the total peatland age or development stage on recent $\mathrm{C}$ accumulation remains uncertain.

[28] We have shown a statistically significant relationship between recent $\mathrm{C}$ accumulation, $\mathrm{N}$ deposition, and climate variables. The highest RERCA during the last 50 years occurred in the high atmospheric $\mathrm{N}$ deposition region, and the reason for this elevated RERCA seemed to be the combination of climate and high $\mathrm{N}$ deposition. Contrary to the results of Okland and Ohlson [1998] in Scandinavian surface peat, the among-peatland variations in $\mathrm{C}$ accumulation and in peat growth rates in eastern Canada were related to climate variables. Supporting our results, a rather clear relationship between long-term $\mathrm{C}$ accumulation and climate characteristics (degree-days and mean annual temperature) has been found for peatland regions in Finland and the mid-Boreal region of Canada [Clymo et al., 1998].

[29] The increased $\mathrm{C}$ accumulation in ombrotrophic hummocks and hollows may be associated with $\mathrm{N}$ as a limiting element in most boreal ecosystems [Malmer, 1990; Aerts et al., 1992]. Wet and dry N deposition, together with $\mathrm{N}$ fixation, are the only $\mathrm{N}$ sources of ombrotrophic peatland systems [Waughman and Bellamy, 1980; Chapman and Hemond, 1982]. N fixation is probably less on hummocks than in the wetter hollows and may increase with increasing temperature and humidity [Urban and Eisenreich, 1988]. Increased C accumulation can also result from a decrease in decomposition rates. Some studies have indicated an increased accumulation of Sphagnum mosses or humus in forest soils with increased N deposition [Malmer, 1990; Berg and Matzner, 1997; Vitt et al., 2003]. Significant changes in the microbial ecology of the peat profile with increasing $\mathrm{N}$
[Gilbert et al., 1998] may lead to reduced heterotrophic respiration in the upper most $5 \mathrm{~cm}$ of the peat profile [Williams and Silcock, 1997]. The atmospheric wet N deposition in eastern Canada $\left(0.3-0.8 \mathrm{~g} \mathrm{~N} \mathrm{~m}^{-2} \mathrm{yr}^{-1}\right)$ is similar to that in Sweden [Aerts et al., 1992] but moderate compared to that in central and western Europe with average levels of $3-4 \mathrm{~g} \mathrm{~N} \mathrm{~m}^{-2} \mathrm{yr}^{-1}$ and up to $8 \mathrm{~g}$ $\mathrm{N} \mathrm{m}^{-2} \mathrm{yr}^{-1}$ [Houdijk and Roelofs, 1991]. Dry $\mathrm{N}$ deposition in eastern Canada is unknown. In areas with high levels of $\mathrm{N}$ deposition, many species typical of bogs and poor fens are decreasing in abundance [Greven, 1992; Tyler and Olsson, 1997]. A nutrient imbalance or a toxic effect might occur in Sphagnum growing under high rates of $\mathrm{N}$ addition, reflected for instance by increased accumulation of amino acids and iron concentrations [Ferguson et al., 1984; Baxter et al., 1992] or decreased photosynthesis and soluble sugar content [van der Heijden et al., 2000]. Vitt et al. [2003] suggest that the negative impacts of net primary production on $S$. fuscum begin to occur, on average, as $\mathrm{N}$ deposition reaches $1.5-$ $1.6 \mathrm{~g} \mathrm{~N} \mathrm{~m}^{-2} \mathrm{yr}^{-1}$. The N-deposition values of our study sites are far below the suggested critical N-deposition values. Jauhiainen et al. [1994] reported that the optimal $\mathrm{N}$ loading for length growth of Sphagnum fuscum was $1 \mathrm{~g} \mathrm{~N} \mathrm{~m}^{-2} \mathrm{yr}^{-1}$, and $3 \mathrm{~g} \mathrm{~N} \mathrm{~m}^{-2} \mathrm{yr}^{-1}$ for biomass production. This suggests that $\mathrm{N}$ loading in our high $\mathrm{N}$ deposition region $\left(\sim 0.8 \mathrm{~g} \mathrm{~N} \mathrm{~m}^{-2} \mathrm{yr}^{-1}\right.$ plus dry deposition) are close to the optimal $\mathrm{N}$ concentrations to stimulate Sphagnum length growth and biomass production. Vitt et al. [2003] found an increase in S. fuscum production with increasing $\mathrm{N}$ deposition in Alberta, Canada. However, the production of $S$. fuscum in continental peatlands may partially be limited by water levels and not nutrients [Thormann and Bayley, 1997; Vitt et al., 2003]. In our study, the aboveground vegetation biomass pattern across the sites did not indicate that the higher rates of recent $\mathrm{C}$ accumulation could be the result of higher biomass production. The most probable explanation for the higher $\mathrm{C}$ accumulation in peat rates may be 
the slower decomposition rate of the organic material [Berg and Matzner, 1997].

[30] The 50-, 100-, and 150-year RERCA of hollows in eastern Canada increased consistently toward the class with the highest growing degree-days above $+5^{\circ} \mathrm{C}$ and the highest $\mathrm{N}$ deposition class, but the elevated $\mathrm{N}$ deposition has been apparent only for the last 50 years. Therefore the higher remaining $\mathrm{C}$ mass in deeper hollow peat layers has to be due to something other than elevated $\mathrm{N}$, that affects higher primary production and/or low decay rates throughout the peat deposits. The $\mathrm{C}$ loss pattern supports the conclusion that both the climate characteristics and the elevated $\mathrm{N}$ control the recent 50 -year $\mathrm{C}$ accumulation in hollows. In hummocks, the significantly higher RERCA was evident only over the last 50 years. The differences in remaining $\mathrm{C}$ mass of deeper hummock layers were insignificant (Figure 4). The results of our study suggest that the moderately high $\mathrm{N}$ deposition has partly increased the present-day $\mathrm{C}$ accumulation both in hollows and hummocks of ombrotrophic peatlands in eastern Canada.

[31] Our results also indicated an inverse relationship between 50-year RERCA and degree-days above $+5^{\circ} \mathrm{C}$ for hollows and hummocks (Figure 3 ). This result may be due to functional difference between microforms and Sphagnum species on ombrotrophic bogs [e.g., Malmer et al., 1994]. The primary production and decay rates of different microforms response to the temperature and the water table fluctuations. The drought and lowered water tables can cause increased oxidation and reduced primary production, resulting in a heavy $\mathrm{C}$ loss [Waddington and Roulet, 1996; Carroll and Crill, 1997], especially in hummocks [Alm et al.,1999].

[32] The recent (RERCA) rates were strikingly higher than the long-term (LORCA) rates of $\mathrm{C}$ accumulation. The LORCA average of $19 \mathrm{~g} \mathrm{C} \mathrm{m}^{-2} \mathrm{yr}^{-1}$ is similar to many other recently published rates $\left(17-21 \mathrm{~g} \mathrm{C} \mathrm{m}^{-2} \mathrm{yr}^{-1}\right)$ [Clymo et al., 1998; Vitt et al., 2000; Turunen et al., 2001, 2002] (Figure 5). Decreased LORCA with increased fire frequency shows that peatland fires (such as at sites 5 and 13) can slow peat accumulation, as individual fires can create C losses of up to 1.5 to $4 \mathrm{~kg} \mathrm{~m}^{-2}$ [Kuhry, 1994; Pitkänen et al., 1999; Robinson and Moore, 2000]. The results of this study revealed no significant relationships between long-term $\mathrm{C}$ accumulation and individual climate characteristics. Also, there was only a weak relationship between LORCA and RERCA. The results indicate that the long-term $\mathrm{C}$ accumulation of eastern Canada has depended on a whole range of climatic, edaphic, and autogenic factors (temperature, precipitation, evapotranspiration, topography, substrate and surficial geology, groundwater flow and chemistry, peat fires). Discrimination among individual factors is difficult.

\subsection{Nitrogen Accumulation}

[33] The average RERNA over the past 50 years ranged from 1.4 to $3.2 \mathrm{~g} \mathrm{~N} \mathrm{~m}^{-2} \mathrm{yr}^{-1}$, depending on the microsite and the $\mathrm{N}$ deposition area (Figure 6). These values are of the same magnitude as the $\mathrm{N}$ accumulation rate $\left(2.0 \mathrm{~g} \mathrm{~N} \mathrm{~m}^{-2} \mathrm{yr}^{-1}\right)$ measured in surface bog peat in southern Sweden [Malmer and Holm, 1984], with similar wet $\mathrm{N}$ deposition rates to eastern Canada [Aerts et al., 1992]. We found that the $\mathrm{N}$ accumulation of peat seemed to increase during the last 50 years compared to the average values for the last 150year period $\left(1.1-2.5 \mathrm{~g} \mathrm{~N} \mathrm{~m}^{-2} \mathrm{yr}^{-1}\right)$. Also, when comparing the remaining $\mathrm{N}$ mass of hummocks and hollows from 100 to 150 years, significant differences were not found between the high and low $\mathrm{N}$ deposition classes.

[34] Woodin and Lee [1987] and Aerts et al. [1992] showed that at high rates of $\mathrm{N}$ deposition the Sphagnum is unable to retain the entire $\mathrm{N}$ deposited on it, and a substantial amount of $\mathrm{N}$ leaches through the surface peat layers. This surplus $\mathrm{N}$ may be taken up by vascular plants or by microorganisms and be a partial cause of the larger vascular plant leaf biomass we found in the highest $\mathrm{N}$ deposition region and/or decomposition and mineralization rates of the peat [e.g., Malmer, 1990]. Our data showed that the $\mathrm{N}$ concentrations in deeper peat layers increased consistently toward the highest $\mathrm{N}$ deposition class. However, it is normal that the highest $\mathrm{N}$ concentrations are found in samples with more decomposed peat and thus higher dry bulk density [Malmer and Holm, 1984], and therefore it is difficult to distinguish the possible increase of $\mathrm{N}$ in deeper peat layers because of leaching.

[35] In summary, we have determined rates of $\mathrm{C}$ accumulation over the past 50 to 150 years in ombrotrophic bogs across eastern Canada, and compare them to the millennial rates. We have shown that the recent rates are correlated with environmental properties, such as climate and atmospheric $\mathrm{N}$ deposition between 1990 and 1996. We suggest that increased $\mathrm{N}$ deposition leads to larger rates of $\mathrm{C}$ and $\mathrm{N}$ accumulation in the bogs, as has been found in European forests [Kauppi et al., 1992; Berg and Matzner, 1997], and could account for some of the missing C sink in the global $\mathrm{C}$ budget. It is possible that fertilization responses, in particular to $\mathrm{N}$, play a significant role in moderate and high anthropogenic deposition areas of North American and European peatlands. In the long term, both the positive and negative impacts for net primary production of Sphagnum species depend on the critical N-deposition loads as suggested by Vitt et al. [2003]. However, there are uncertainties associated with covarying properties. These uncertainties include the influence of climate, such as precipitation, temperature, and pollutant emissions, on rates of plant production and decomposition, disturbances such as fire, and pre-1990 rates of atmospheric $\mathrm{N}$ deposition.

[36] Acknowledgments. We thank Climate Change Action Fund (CCAF) and NSERC for their financial support of this research, and C. Blodau of the University of Bayreuth for the $\mathrm{C}$ and $\mathrm{N}$ analyses. J. T. received partial funding from the FCAR-supported Centre for Climate and Global Change Research for his postdoctoral fellowship.

\section{References}

Aerts, R., B. Wallen, and N. Malmer (1992), Growth-limiting nutrients in Sphagnum-dominated bogs subject to low and high atmospheric nitrogen supply, J. Ecol., 80, 131-140.

Alm, J., L. Schulman, J. Walden, H. Nykänen, P. J. Martikainen, and J. Silvola (1999), Carbon balance of a boreal bog during a year with an exceptionally dry summer, Ecology, 80, 161-174.

Appleby, P. G., and F. R. Oldfield (1978), The calculation of ${ }^{210} \mathrm{~Pb}$ dates assuming a constant rate of supply of unsupported ${ }^{210} \mathrm{~Pb}$ to the sediment, Catena, $5,1-8$. 
Appleby, P. G., W. Shotyk, and A. Fankhauser (1997), Lead-210 age dating of three peat cores in the Jura Mountains, Switzerland, Water Air Soil Pollut., 100, 223-231.

Baxter, R., M. J. Emes, and J. A. Lee (1992), Effects of an experimentally applied increase in ammonium on growth and amino-acid metabolism of Sphagnum cuspidatum Ehrh. ex. Hoffm. from differently polluted areas, New Phytol., 120, 265-274.

Belyea, L. R. (1996), Separating the effects of litter quality and microenvironment on decomposition rates in a patterned peatland, Oikos, 77 $529-539$.

Belyea, L. R., and B. G. Warner (1994), Dating of the near-surface layer of a peatland in northwestern Ontario, Canada, Boreas, 23, 259-269.

Berendse, F., et al. (2001), Raised atmospheric $\mathrm{CO}_{2}$ levels and increased $\mathrm{N}$ deposition cause shifts in plant species composition and production, Global Change Biol., 7, 591-598.

Berg, B., and E. Matzner (1997), Effect of N deposition on decomposition of plant litter and soil organic matter in forest systems, Environ. Rev., 5 , $1-25$.

Botch, M. S., K. I. Kobak, T. S. Vinson, and T. P. Kolchugina (1995), Carbon pools and accumulation in peatlands of the Former Soviet Union, Global Biogeochem. Cycles, 9, 37-46.

Carroll, P. C., and P. Crill (1997), Carbon balance of a temperate poor fen, Global Biogeochem. Cycles, 11, 349-356.

Chapman, R. R., and H. F. Hemond (1982), Dinitrogen fixation by surface peat and Sphagnum in an ombrotrophic bog, Can. J. Bot., $60,538-543$

Clymo, R. S. (1984), The limits to peat bog growth, Philos. Trans. R. Soc. London, Ser. B, 303, 605-654.

Clymo, R. S., J. Turunen, and K. Tolonen (1998), Carbon accumulation in peatland, Oikos, 81, 368-388.

Damman, A. W. H. (1978), Distribution and movement of elements in ombrotrophic peat bogs, Oikos, 30, 480-495.

Damman, A. W. H. (1988), Regulation of nitrogen removal and retention in Sphagnum bogs and other peatlands, Oikos, 51, 291-305.

Damman, A. W. H., and J. J. Dowhan (1981), Vegetation and habitat conditions in Western Head Bog, a southern Nova Scotian plateau bog, Can. J. Bot., 59, $1343-1359$.

El-Daoushy, F., K. Tolonen, and R. Rosenberg (1982), Lead 210 and mossincrement dating of two Finnish Sphagnum hummocks, Nature, 296, $429-431$.

Ferguson, P., R. N. Robinson, M. C. Press, and J. A. Lee (1984), Element concentrations in five Sphagnum species in relation to atmospheric pollution, J. Bryol., 13, 107-114.

Gilbert, D., C. Amblard, G. Bourdier, and A.-J. Francez (1998), Short-term effect of nitrogen enrichment on the microbial communities of a peatland, Hydrobiology, 373/374, 111-119.

Glaser, P. H., and J. A. Janssens (1986), Raised bogs in eastern North America: Transitions in landforms and gross stratigraphy, Can. J. Bot., $64,395-415$.

Gorham, E. (1990), Biotic Impoverishment in Northern Peatlands, in The Earth in Transition: Patterns and Processes of Biotic Impoverishment, edited by G. M. Woodwell, pp. 65-98, Cambridge Univ. Press, New York.

Gorham, E. (1991), Northern Peatlands: Role in the carbon cycle and probable responses to climatic warming, Ecol. Appl., 1, 182-195.

Gorham, E., S. J. Eisenreich, J. Ford, and M. V. Santelmann (1985), The chemistry of bog waters, in Chemical Processes in Lakes, edited by W. Stumm, pp. 339-363, Wiley-Intersci., John Wiley, New York.

Greven, H. C. (1992), Changes in the moss flora of the Netherlands, Biol. Conserv., 59, $133-137$.

Houdijk, A. L. F. M., and J. G. M. Roelofs (1991), Deposition of acidifying and eutrophicating substances in Dutch forests, Acta Bot. Neerl., 40, $245-255$.

Houghton, J. T., G. J. Jenkins, and J. J. Ephraums (1990), Climate Change, The IPCC Scientific Assessment, Cambridge Univ. Press, New York.

Houghton, R. A. (1993), Is carbon accumulating in the northern temperate zone?, Global Biogeochem. Cycles, 7, 611-617.

Jauhiainen, J., H. Vasander, and J. Silvola (1994), Response of Sphagnum fuscum to $\mathrm{N}$ deposition and increased $\mathrm{CO}_{2}$, J. Bryol., 18, 83-95.

Kauppi, P. E., K. Mielikäinen, and K. Kuusela (1992), Biomass and carbon budget of European forests, Science, 256, 70-74.

Kuhry, P. (1994), The role of fire in the development of Sphagnumdominated peatlands in western Boreal Canada, J. Ecol., 82, 899-910.

Lafleur, P. M., N. T. Roulet, and S. W. Admiral (2001), Annual cycle of $\mathrm{CO}_{2}$ exchange at a bog peatland, J. Geophys. Res., 106, 3071-3081.

Lindholm, T., and H. Vasander (1990), Production of eight species of Sphagnum at Suurisuo mire, southern Finland, Ann. Bot. Fenn., 27, $145-157$.
Livett, E. A., J. A. Lee, and J. H. Tallis (1979), Lead, zinc, and copper analysis of British blanket peats, J. Ecol., 67, 865-891.

Malmer, N. (1990), Constant or increasing nitrogen concentrations in Sphagnum mosses on mires in Southern Sweden during the last few decades, Aquilo Ser. Bot., 28, 57-65.

Malmer, N., and E. Holm (1984), Variation in the C/N-quotient of peat in relation to decomposition rate and age determination with ${ }^{210} \mathrm{~Pb}$, Oikos, $43,171-182$.

Malmer, N., B. M. Svensson, and B. Wallen (1994), Interactions between Spagnum and field layer vascular plants in the development of peatforming systems, Folia Geobot. Phytotaxon., 29, 483-496.

Mitchell, P. I., W. R. Schell, A. McGarry, T. P. Ryan, J. A. Sanchex-Cabeza, and A. Vidal-Quadras (1992), Studies of the vertical distribution of ${ }^{134} \mathrm{Cs}$, ${ }^{137} \mathrm{Cs},{ }^{238} \mathrm{Pu},{ }^{23,9249} \mathrm{Pu},{ }^{241} \mathrm{Pu},{ }^{241} \mathrm{Am}$ and ${ }^{210} \mathrm{~Pb}$ in ombrogenous mires at mid-latitudes, J. Radioanal. Nucl. Chem., 156, 361-387.

Moore, T. R., J. L. Bubier, S. E. Frolking, P. M. Lafleur, and N. T. Roulet (2002), Plant biomass and production and $\mathrm{CO}_{2}$ exchange in an ombrotrophic bog, J. Ecol., 90, 25-36.

Ohlson, M. O., and B. Dahlberg (1991), Rate of peat increment in hummocks and lawn communities on Swedish mires during the last 150 years, Oikos, 61, 369-378.

Økland, R. H., and M. Ohlson (1998), Age-depth relationships in Scandinavian surface peat: A quantitative analysis, Oikos, 82, 29-36.

Oldfield, F., P. Appleby, R. Cambray, J. Eakins, K. Barber, R. Batterby, G. Pearson, and J. Williams (1979), $\mathrm{Pb}-210$, Cs-137, and $\mathrm{Pu}-239$ profiles in ombrotrophic peat, Oikos, 33, 40-45.

Oldfield, F., N. Richardson, and P. G. Appleby (1995), Radiometric dating $\left({ }^{210} \mathrm{~Pb},{ }^{137} \mathrm{Cs},{ }^{241} \mathrm{Am}\right)$ of recent ombrotrophic peat accumulation and evidence for changes in mass balance, Holocene, 5, 141-148.

Pakarinen, P., K. Tolonen, S. Heikkinen, and A. Nurmi (1983), Accumulation of metals in Finnish raised bogs, Environ. Biogeochem., 35, 377-382.

Pitkänen, A., J. Turunen, and K. Tolonen (1999), The role of fire in the carbon dynamics of a mire, Eastern Finland, Holocene, 9, 453-462.

Post, W. M., W. R. Emanuel, P. J. Zinke, and A. G. Stangenberger (1982), Soil carbon pools and world life zones, Nature, 298, 156-159.

Robinson, S. D., and T. R. Moore (2000), The influence of permafrost and fire upon carbon accumulation in high boreal peatlands, Northwest Territories, Canada, Arct. Alp. Res., 32, 155-166.

Shotyk, W., A. K. Cheburkin, P. G. Appleby, A. Fankhauser, and J. D. Kramers (1997), Lead in three bog profiles, Jura Mountains, Switzerland: Enrichment factors, isotopic composition, and chronology of atmospheric deposition, Water Air Soil Pollut., 100, 297-310.

Sjörs, H. (1959), Bogs and fens in the Hudson Bay lowlands, J. Arct. Inst. North Am., 12, 1-19.

Stuiver, M., and P. J. Reimer (1993), Extended ${ }^{14} \mathrm{C}$ data base and revised CALIB $3.0{ }^{14} \mathrm{C}$ age calibration program, Radiocarbon, 35, 215-230.

Tabatabai, M. A., and J. M. Bremer (1990), Automated instruments for determination of total carbon, nitrogen, and sulfur in soils by combustion techniques, in Soil Analysis: Modern Instrumental Techniques, 2nd ed., edited by K. A. Smith, pp. 261-286, Marcel Dekker, New York.

Tans, P. P., I. Y. Fung, and T. Takahashi (1990), Observational constraints on the global atmospheric $\mathrm{CO}_{2}$ budget, Science, 247, 1431-1438.

Thormann, M. E., and S. E. Bayley (1997), Response of above ground net primary plant production in nitrogen and phosphorous fertilization in peatlands in southern boreal, Alberta, Canada, Wetlands, 17, 502-512.

Tolonen, K., and J. Turunen (1996), Accumulation rates of carbon in mires in Finland and implications for climate change, Holocene, 6, 171-178. Tolonen, K., R. B. Davis, and L. Widoff (1988), Peat accumulation rates in selected Maine peat deposits, Maine Geological Survey, Dep. Conserv. Bull., 33, 1-99.

Turetsky, M. R., R. K. Wieder, C. J. Williams, and D. H. Vitt (2000), Organic matter accumulation, peat chemistry, and permafrost melting in peatlands of boreal Alberta, Ecoscience, 7, 379-392.

Turunen, J., A. Pitkänen, T. Tahvanainen, and K. Tolonen (2001), Carbon accumulation in West Siberian mires, Russia, Global Biogeochem. Cycles, 15, 285-296.

Turunen, J., E. Tomppo, K. Tolonen, and A. Reinikainen (2002), Estimating carbon accumulation rates of undrained mires in Finland: Application to boreal and subarctic regions, Holocene, 12, 69-80.

Tyler, G., and K.-A. Olsson (1997), Förändringar I Skånes flora under perioden 1938-1996-Statistisk analys av resultat från två inventeringar (Changes in the flora of Scania during the years 1938-1996), Sven. Bot. Tidskr., 91, 143-185.

Urban, N. R., and S. J. Eisenreich (1988), Nitrogen cycling in a forested Minnesota bog, Can. J. Bot., 66, 435-449.

Urban, N. R., S. J. Eisenreich, D. F. Grigal, and K. T. Schurr (1990), Mobility and diagenesis of $\mathrm{Pb}$ and ${ }^{210} \mathrm{~Pb}$ in peat, Geochim. Cosmochim. Acta, 54, 3329-3346. 
van der Heijden, E., S. K. Verbeek, and P. J. C. Kuiper (2000), Elevated atmospheric $\mathrm{CO}_{2}$ and increasing nitrogen deposition: Effects on $\mathrm{C}$ and $\mathrm{N}$ metabolism and growth of the peat moss Sphagnum recurvum P. Beauv. var. mucronatum (Russ.) Warnst, Global Change Biol., 6, $201-212$.

Vet, R., C. U. Ro, and D. Ord (1999), SOE technical supplement, Bull. 993, Natl. Atmos. Chem. Database and Anal. Facil., Atmos. Environ. Serv., Environ. Can., Ontario, Canada.

Vile, M. A., M. J. V. Novak, E. Brizova, R. K. Wieder, and W. R. Schell (1995), Historical rates of atmospheric $\mathrm{Pb}$ deposition using ${ }^{210} \mathrm{~Pb}$ dated peat cores: corroboration, computation, and interpretation, Water Air Soil Pollut., 79, 89-106.

Vile, M. A., R. K. Wieder, and M. Novak (1999), Mobility of $\mathrm{Pb}$ in Sphagnum-derived peat, Biogeochemistry, 45, 35-52.

Vitt, D. H., L. A. Halsey, I. E. Bauer, and C. Campbell (2000), Spatial and temporal trends in carbon storage of peatlands of continental western Canada through the Holocene, Can. J. Earth Sci., 37, 683693.

Vitt, D. H., K. Wieder, L. A. Halsey, and M. Turetsky (2003), Response of Sphagnum fuscum to nitrogen deposition: A case study of ombrogenous peatlands in Alberta, Canada, Bryologist, 235-245.

von Post, L. (1922), Sveriges geologiska undersöknings torvinventering och några av dess hittills vunna resultat, Sven. Mosskulturfören. Tidskr., $1,1-27$
Waddington, J. M., and N. T. Roulet (1996), Atmosphere-wetland carbon exchanges: Scale dependency of $\mathrm{CO} 2$ and $\mathrm{CH} 4$ exchange on the developmental topography of a peatland, Global Biogeochem. Cycles, 10, $233-245$.

Waughman, G. J., and D. J. Bellamy (1980), Nitrogen fixation and the nitrogen balance in peatland ecosystems, Ecology, 61, 1185-1198.

Wieder, R. K., M. Novak, W. R. Schell, and T. Rhodes (1994), Rates of peat accumulation over the past 200 years in five Sphagnum-dominated peatlands in the United States, J. Paleolimnol., 12, 35-47.

Williams, B. L., and D. J. Silcock (1997), Nutrient and microbial changes in the peat profile beneath Sphagnum magellanicum in response to additions of ammonium nitrate, J. Ecol., 34, 961-970.

Woodin, S. J., and J. A. Lee (1987), The fate of some components of acidic deposition in ombrotrophic mires, Environ. Pollut., 45, 61-72.

T. R. Moore, N. T. Roulet, and J. Turunen, Department of Geography, McGill University, 805 Sherbrooke Street West, Montréal, Québec, H3A 2K6, Canada. (tim.moore@mcgill.ca; nigel.roulet@mcgill.ca; jukka. turunen@gtk.fi)

P. J. H. Richard, Département de Géographie, Université de Montréal, C.P. 6128 Centre-ville, Montréal, Québec, H3C 3J7, Canada. (pierre. richard@umontreal.ca) 